\title{
The strategy in increasing creative economy during the COVID-19 pandemic
}

\section{Yuliana Yuliana}

Fakultas Kedokteran, Universitas Udayana, Denpasar, Indonesia

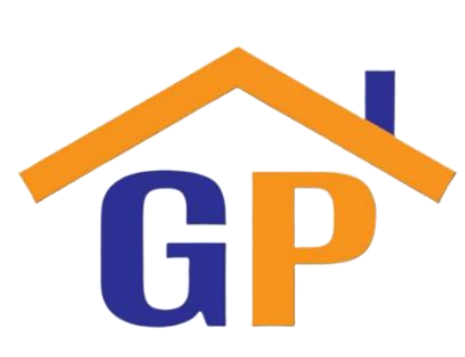

Article History

Received on 15 May 2021

Revised on 1 June 2021

Accepted on 9 June 2021

\begin{abstract}
Purpose: This paper aimed to comprehend the strategy to increase the creative economy during the pandemic, especially about ecommerce and supply chain.
\end{abstract}

Research methodology: This is a review of the literature. This paper used the database in Science Direct and Google Scholar. The keywords used were COVID-19, creative economy, e-commerce, increase, supply chain, and strategy.

Results: The effectiveness of the supply chain can be improved by analyzing the strengths, weaknesses, opportunities, and challenges (SWOT) so that strengths and opportunities can be optimized. Ecommerce can be increased by enhancing creativity and innovation. Another way is cooperating with the government and other entrepreneurs.

Limitations: This paper is a narrative literature review. There are only a few studies about e-commerce and the supply chain during the COVID-19 pandemic in this paper. Further studies are needed to increase the e-commerce and supply chain for each item and commodities during the COVID-19 pandemic.

Contribution: The contribution of this paper is for the creative economy in increasing the effectiveness of supply chains and ecommerce.

Keywords: COVID-19, Creative economy, E-commerce, Increase, Supply chain, Strategy

How to cite: Yuliana. Y. (2021). The strategy in increasing creative economy during the COVID-19 pandemic. Journal of Sustainable Tourism and Entrepreneurship, 2(2), 109-118.

\section{Introduction}

In line with globalization in the economic and technological fields, there is rapid development in the technology of the business world. On the other hand, social networks have become more complex because of the internet. Artificial intelligence technology can also be used in online business. However, sometimes it is a little challenging to set up an online product. Therefore, the right strategy is needed to increase the income for the new enterprise, especially for small and medium enterprises (SME) (Wu \& Han, 2021).

The conditions of the COVID-19 pandemic have made the online business industry getting more and more. However, the uncertain condition of COVID-19 sometimes makes it difficult for supply chain managers. The preferences of these consumers are changing very quickly. Therefore, it is necessary to analyze the factors that affect the performance and competitive ability of the industry to do creative innovation to create optimal efforts. The development strategy is very important because it provides information and the preparation of money, goods, innovation, and the development of knowledge, efficiency, and value. This analysis is important for knowing the map of the strengths of the business. The analysis that is commonly used is the analysis of Strengths, Weaknesses, Opportunities, and Threats (SWOT). This is very important to determine alternative strategies. For a focused strategy, the methods of Quantitative Strategic Planning Matrix (QSPM) are important in planning strategies taking into account the total value of interest (total attractiveness scores) (Heryani et al., 2020). 
Analysis of the strengths and weaknesses of internal and external factors is also fundamental. Internal factors consisting of strengths and weaknesses are referred to as the Internal Factor Evaluation (IFE) matrix. External factors consist of opportunities and threats. These factors are known as the External Factor Evaluation (EFE) matrix. All of these things play an important role in the creative industry development for the creation of innovation (Heryani et al., 2020).

Selection of strategy and decision used the method of Quantitative Strategic Planning Matrix (QSPM). QSPM calculation is obtained from the average of internal factors and external factors with the acquisition of the Total Attractive Score. Attractive Total Score using the greatest value in the preparation of the strategy according to the key success factors, both internal and external factors. These factors have been previously identified as top priority strategies. Next, the second priority is identified, and so on (Ibrahim et al., 2019; Zulkarnain et al., 2018). The analytical hierarchy process (AHP) is also used to determine appropriate strategies for recommendations for small and medium enterprises during the COVID-19 pandemic (Dewantoro \& Saogo, 2021).

Heryani et al. conduct an analysis of the Internal Environment for Small and Medium Enterprises. The research group is the partner of the researcher. These groups are the Galoeh Bandjar and Al Firdaus groups. They have a creative industry business in the form of purun crafts. The forms of handicrafts include bags, coating for plant pots, mats, prayer mats, wall decoration creations, and so on. Purun is nothing but a typical swamp plant from South Kalimantan. This effort developed with the help of the human resources of the local area, namely women and housewives. The hope is that SMEs can continue to run during the Covid 19 pandemic. In the conditions of the COVID-19 pandemic, all UKM activities will continue to be carried out while still implementing rigorous health protocols to reduce the risk of transmission of the COVID-19 virus to workers, families, and the surrounding community (Heryani et al., 2020). With the COVID-19 pandemic, the business sector experiences a decline. This condition requires supply chain management to have a special integration system. A suitable integration system will improve the research climate. Apart from the supply chain system, another important factor is ecommerce (Heryani et al., 2020).

The existence of e-commerce is increasingly felt at a time when the development of information technology is increasing. People's lives are made easier by the existence of information technology. This is also felt in the world of commerce. The sophistication of information technology will greatly help business, industry, and trade. Even now, in Indonesia, the growth of e-commerce has reached five times in the last four years (Hendarsyah, 2019). The industrial era 4.0 and society 5.0 are the era of technology transformation to digital. The way of life and shopping habits have also changed. This brings significant progress and improvement in the advancement of e-commerce. Technology e-commerce thrives in era industry 4.0 and society 5.0. The prospect of e-commerce growth will increase in the future (Hendarsyah, 2019). The existence of e-commerce makes it easier to create business activities so that jobs can be created creatively, not depending on the government. Economic independence will be more accessible with e-commerce. The competition will be healthier in the e-commerce business (Asmah, 2019).

The purpose of this paper is to explain strategies to improve the creative economy during the COVID19 pandemic, especially focused on supply chains (supply chains) and online business (e-commerce). In addition, ways to improve supply chain management, analysis of the strengths and weaknesses of the creative industry, as well as ways to increase the competitive advantage of creative industry businesses will also be discussed in the following sections.

\section{Literature review and hypothesis development}

Previous research was by Heryani et al. (2020). from August to October 2020. It involved two groups of craftsmen in Banjarbaru, South Kalimantan. The analysis results revealed that the most important was the availability of potential resources, then the next was the understanding of market changes rapidly and building partnerships. A good industry must have a principle of efficiency to improve competitiveness, also have standardized and sustainable products. It is also important to be responsive 
to market demands. All of these will enhance the innovation development strategy of the creative industry economy (Heryani et al., 2020).

Supply chain research of frozen catfish fillets in the form of a case study at CV. With locations in the village of Koto Mesjid the District XIII Koto Kampar Kampar, Graha Pratama Fish indicated that the supply chain systems from December 2018 until January 2019 were already well implemented. The most important thing for the efficiency of the catfish supply chain is the sensitivity of cash to cash cycle time (Fauziah \& Vaulina, 2020).

Research done in Bandung in a creative industry revealed that a differentiation strategy was needed to survive in the competitive market. Plagiarism is relatively high in the middle of the creative industry. Therefore, based on SWOT analysis, business strategy, and function, it was found that a differentiation strategy coupled with collaboration with the government and other entrepreneurs in the creative industry sector needs to be continuously fostered to achieve an increase in production and effective marketing. To prevent plagiarism, the product needs to be patented (Herawaty \& Raharja, 2018).

According to Budiono, the market penetration strategy is market development and product development. However, the integrative strategy also plays an important role. This integrative strategy is divided into three directions, namely forward, backward, and horizontal integration. Forward integration means gaining broader influence, control, or ownership over distributors or representatives. Backward integration means seeking ownership or control of the supplier, which is much larger. Horizontal integration means seeking greater ownership and control than competitors in the market (Budiono, 2017).

New technologies in the form of Virtual-Reality, Augmented-Reality, and Mixed-Reality provide consumers with separate moments and experiences regarding a new environment where physical and virtual objects are integrated at different levels. The development of tools, technology, and internet connections has made the consumer experience a combined experience known as a hybrid experience. The concept of combination and integration between technology (embodiment), psychology (presence or existence), and behavior (interactivity) is given a new taxonomic term, namely EPI Cube. This novelty will certainly provide an exciting experience for consumers ((Flavián et al., 2019).

The mutual relationship between buyers and suppliers is significant to improve performance. Trust is the main factor in fostering a successful relationship in buying and selling transactions. Research conducted by Rajput et al. shows that supplier performance improvement is needed to enhance industrial development. Another important thing is the supplier's ability to handle quality, delivery, and control over his manufactured goods and merchandise (Rajput et al., 2019).

Applying the concept of competitive advantage for the small and medium-sized business sector can increase the ability to compete in today's globalized world. There are lots of competitors out there ready to pounce on others at any moment. However, if there is a strong endurance and ability to innovate, then the economy will be more advanced and creative. Creating a competitive advantage in small and medium enterprises is a major factor that plays a role in increasing the company's ability to create an added value (Zultaqawa et al., 2020).

Cooperation between the government, research institutions, and academia is very important to create a competitive advantage that is needed by the creative industry today. This competitive advantage is the company's strategy to be able to compete in the market turmoil by reducing costs, increasing market opportunities, and neutralizing the threat of competition it faces. Thus, competitive advantage considers the aspects of cost leadership, opportunities, and avoiding competitive threats. If the threat in trade competition increases, it will take extra effort to overcome the competition. This extra effort is called a competitive advantage (Zultaqawa et al., 2020).

The increase in companies that offer similar goods and services to consumers causes increased competition. This competition can provide advantages, namely increasing competitive advantage and 
creativity. For example, various companies will compete to provide lower prices and better service. Another alternative is to provide the same price but better quality. Based on the theory of resources (Resource-based theory), in the chapter on creating and maintaining competitive advantage, it turns out that the source of competitive advantage is a genuine resource, cannot be imitated, and has no substitute. Resources here include all assets, capabilities, organizational processes, company characteristics, knowledge, information, and others. All of these things are important to achieve an effective strategy in achieving competitive advantage (Zultaqawa et al., 2020). However, based on data in the field, there are still very few studies that discuss the competitive advantage of small and medium enterprises. Various studies are more focused on large-scale companies. Small and medium enterprises have their uniqueness that can guide winning the competition (Zultaqawa et al., 2020).

Competitive advantage is very important to observe because of competition in the world of globalization. Such a situation causes actions and reactions between various companies and industries to occur more rapidly. Nevertheless, entrepreneurs who can implement a competitive advantage strategy will survive (Zultaqawa et al., 2020). Business theory is a dynamic thing. The increasing value must continue to be pursued if the businessman has a passion for growing. Companies can increase added value by reacting to copycats, creating new marketing strategies, and paying better attention to environmental factors. A good business must continue to change according to the times, so a business cannot remain in a static state. There are several themes of business transformation models. These themes include the availability of new technologies, macroeconomic trends, institutional changes, and product marketing strategies. The validity of a product must be adequately tested before being launched to consumers. A good product will increase an added value (Climent \& Haftor, 2021).

\section{Research methodology}

The method used in the writing of this paper is a literature review. The database used in this literature review were the Science Direct and Google Scholar databases. The keywords used were COVID-19, ecommerce, creative economy, increase, supply chain, strategy. After screening by the title, abstract, and overall content, there were a total of 18 articles. Inclusion criteria are review and research. Exclusion criteria are short notes and commentaries. Journal selection is based on contribution, contrast, and comparison. Finally, the selected journals are summarized. The summary results are presented in a narrative literature review.

\section{Results and discussions}

\subsection{Supply chain management}

Supply chain management is an integrated system that can synchronize a business process from raw materials to suppliers so that distribution activities to consumers run smoothly. Thus, profit and operations run well. The main essence of the supply chain is the flow of products, finance, and information (Fauziah \& Vaulina, 2020; Heryani et al., 2020). Industrial activities that run smoothly will provide an added value. This is important to ensure good supply chain performance. New strategies and innovations are needed to survive in the business competition (Heryani et al., 2020).

\subsection{E-commerce}

The existence of sluggish economic conditions due to the COVID-19 pandemic requires innovative strategies so that they can continue to increase sales. Malls and shopping areas are empty of visitors. Some companies implement a system to work from home. It is very flexible to reduce travel time going to and from the office. Therefore, the role of e-commerce can be enhanced. There will be a little change in the goods transport system towards the consumers (Heryani et al., 2020).

Data available at the General Directorate of Land Transportation in 2020 shows an increase in transactions at e-commerce by IDR 12 million. This time of the COVID-19 pandemic is the right time for the rise of e-commerce. The existence of e-commerce can improve the economy of Indonesia and the world globally (Heryani et al., 2020).

E-commerce provides convenience for consumers by providing a variety of products. Health care products, food, crafts, electronic goods, books, and internet services can be purchased through e- 
commerce (Heryani et al., 2020). Internet subscribers have increased to more than 80 million compared to before COVID-19. This condition is good to improve e-commerce development (Saragih et al., 2020).

A marketplace that is in e-commerce reveals faster and attractive appearances in offering unique products. This is quite practical because it is done without face-to-face contact. All transactions are done online with the help of the internet. Thus, there is a change in logistics and distribution in the required product supply chain. Transaction mode uses digital mode. Therefore, the transaction must be smooth and safe. Privacy and security of the customers have to be guaranteed (Saragih et al., 2020). The smooth running of this logistics service is very important. This is related to the delivery of products from producers to distributors, then distributed to retailers, and finally in the hands of consumers. The existence of information and communication technology greatly accelerates the distribution and delivery of products (Saragih et al., 2020).

The supply chain structure will change according to the location, process, production capacity, and warehouse, which can be adapted as a special system. Therefore, the development of creative industries through Micro and Small and Medium Enterprises (MSMEs) using information technology will be an important strategy in increasing business opportunities (Heryani et al., 2020). Bandung and Surabaya are the two largest cities that utilize e-commerce in carrying out the creative economy. Internet access makes businesses run more smoothly through e-commerce. The existence of the e-commerce business can reduce monopoly and unfair competition. Various innovations are needed to improve the performance of the creative economy. The government can help by improving the quality of internet networks that have high speed for all regions in Indonesia, from Sabang to Merauke, to create equity. The government can provide training facilities and competency certification to improve the competence of workers in facing globalization. Vocational education can also be provided to improve graduates' abilities so that they are ready to work in the field when they graduate (Asmah, 2019).

\subsection{Creative industries and creative economy}

Creative industry activities will encourage the success of the creative economy. The creative industry is an industry that uses creativity, innovation, and the skills possessed by a person to produce ideas or products. Creative industries involve the process of production, distribution, exchange, and consumption of products or services. Resources have the largest role in the creative industries. An important role in the creative industries is also held by human resources quality. Workers must be skilled and trained. They should have the essential knowledge, creativity, and innovation (Heryani et al., 2020). The creative industries play an important role in urban regeneration. The creative industries will create employment for a region, as well as increasing development of economic development. The growth of creative industries is related to economic restructuring. This has caused the city's economic base to shift from manufacturing/factory to service-based and knowledge-intensive industries. Several countries are trying hard to increase competitiveness in the international environment and get the opportunity to create a creative economy (Heryani et al., 2020).

The strategy to increase the creative economy will influence the performance and competitiveness of the creative industry. The result will be innovation for progress and development in new normal conditions based on information technology. It is essential for disseminating the habit of critical thinking and build solidarity. The solidarity of the team is very critical to enhance the creative economy industry. A business person must try to evaluate the strength of the fighting in the arena of global competition. All of them are essential to increase the business values (Heryani et al., 2020).

There are three dimensions in sustainable development, namely economic growth, environmental sustainability, and social development. The development of the creative industry is very important in making a positive contribution to the creation of innovation, the business climate, and the formation of creativity. All of it should be supported by qualified human resources, advanced technology, industry, resource, and financial institutions. In this case, the role of the government is very much needed for the development of the creative industry in MSMEs (Heryani et al., 2020). 
A qualified human resource is the main capital and a key factor in the development of the creative industry. This is very important in the struggle to face competition in the era of Industry 4.0. The quality of human resources can be improved through training, education, and mentoring. These strategies are expected to support the acceleration and development of a sustainable creative economy. The creative economy in Indonesia includes 16 creative industries as follows: (1) Architecture; (2 ) Visual communication design; (3) Interior design; (4) Product design; (5) Photography; (6) Films, animations, and videos; (7) Crafts; (8) Culinary arts; (9 ) Mode; (10) Music; (11) Application and game development; (12) Advertising; (13 ) Publishing; (14) Television and radio; (15) Fine arts; and (16) Performing arts. Those creative economy industries are assessed using planning and development to describe the importance of the contribution of the creative economy to sustainable development, especially in efforts to support the goals of sustainable development (Lestariningsih et al., 2018).

\subsection{The analysis of internal factors in the creative economy industry}

The analysis of internal factors in the creative economy industry is divided into strength and weakness factors. In his research, Heryani et al. found an analysis of internal factors in the form of strength, namely natural potential that supports the growth of commodities as basic raw materials, availability of resources as raw materials, product standardization, the need for sustainable partnerships, and female workers who are always ready after completing routine activities in their respective households respectively. On the other hand, the disadvantages are that a lot of time is wasted in the production process, the time effectiveness for a particular product is not known, and the lack of comprehensive and sustainable standardization (Heryani et al., 2020).

\subsection{The analysis of external factors in the creative economy industry}

The analysis of external factors includes opportunities and challenges (threats). The external factors were analyzed using the matrix of External Factor Evaluation (EFE). Heryani et al. studied a group of small and medium-sized businesses that are producers of purun handicrafts in South Kalimantan. They found that the greatest value for the development of creative industries was achieved by innovation. The existing innovations will be able to overcome all the challenges that lie ahead and take advantage of opportunities as much as possible for economic progress and the creative industry. The factors included in the opportunity are various policies and regulations during the COVID-19 pandemic, support, and synergy in partnership programs, market share to deal with rapid market changes, the existence of several tourist attractions in small and medium business areas, as well as locations close to the city center. However, despite the many opportunities that lie ahead, there are still challenges and upheavals that must be faced. The various challenges are competitions between one small and medium business with other businesses. An entrepreneur should improve the quality of human resources so that they can diversify products. They must build the networks so that the quality of mastery of technology and information is increasing. The standardization is carried out. Building collaborations to strengthen and develop effective information technology will create qualified human resources ready to face storms in this digital era (Heryani et al., 2020).

The ability to master technology greatly determines the development of ideas and creativity achieved by industry. Human resources who have expertise in using technology well will be winners in the competition in various industrial businesses. Information and communication technology is very important for obtaining, disseminating, and exchanging information and creative ideas in the chain of creations of a creative industry. On the other hand, communication and information technology are very crucial in the transaction process and promotion in the distribution chain and commercialization (Alexandri et al., 2019).

An innovation activity requires the addition of ideas and creativity. The added value obtained can be through natural resources or land, services, or other products. This will be the main support in the progress of the creative industry. Therefore, environmentally friendly products remain an important factor that should not be forgotten (Heryani et al., 2020). The strategies for enhancing the creative economy industry are market penetration and product development so that it can develop the market. This condition can be achieved by expanding market share. The steps that can be taken are increasing marketing, promotion, and product development activities. Products can be developed by improving 
the quality of the product so that it is of higher quality. Product innovation in the form of economical packaging so that it is cheaper and easier to buy for consumers, developing new product variations so that consumers don't get bored is equally important. One way to win from competitors is with a unique selling concept (USP) (Heryani et al., 2020).

The creative industry sector greatly relies on the innovation of human resources (HR) in the production process. Almost all products in the sub-creation industry sector are highly dependent on people's tastes, orders from consumers, as well as the latest trends or trends that are popular. Creativity and ideas of human resources for innovation are crucial for improving the competitiveness of the product concerned. Generating innovation must be accompanied by a mindset that is always innovative and modern. This is for the sake of achieving creativity. Creativity can create development and success for the creative industry. Promotion can be done through social media such as Instagram, Facebook, or TikTok, as well as websites (Heryani et al., 2020).

\subsection{Matrix of Strength, Weakness, Opportunities, and Threats (SWOT) analysis}

The analysis results obtained from internal factors and external factors of an industry can be continued with the preparation of various alternative strategies. The strategy to be taken refers to the analysis of Strength, Weakness, Opportunities, and Threats (SWOT). By analyzing the SWOT chart, alternative strategies will be obtained and adjustments and conditioning between strengths and weaknesses against opportunities and various challenges and threats that must be faced in the industrial world. This adjustment stage is also known as the matching stage (Heryani et al., 2020).

Several alternative strategies that need to be implemented by the creative industry to overcome weaknesses and avoid threats or challenges that confront are as follows (Heryani et al., 2020):

a) Increase the availability of various potential resources

b) Improve and improve the quality of all standardized products on an ongoing basis

c) Developing the principle of efficiency to increase competitiveness

d) Build partnerships effectively and broadly

e) Control and manage all changes that occur in the market appropriately and quickly

f) Analysis of Quantitative Strategic Planning Matrix (QSPM)

The analysis is carried out to determine the priority of the first, second, third, and subsequent strategies, namely through the Quantitative Strategic Planning Matrix (QSPM). QSPM strategy was developed through an internal matrix, external matrix, and SWOT analysis. Thus, the most appropriate strategy will be obtained for the development of the creative industry to achieve the latest innovations so that they can compete in the market (Heryani et al., 2020).

Quantitative Strategic Planning Matrix (QSPM) analysis data is useful to produce a creative industry development strategy. The results show that the main priority is the importance of the availability of potential resources. Furthermore, the second priority is understanding the market changes that occur, increasing partnerships, making standardized and sustainable products, and increasing the principle of efficiency for competitiveness. Customers are the target of innovation and USP. Products that can be purchased directly or online will make it easier for customers (Heryani et al., 2020).

Training and coaching are very important to strengthen branding. The market goes through very rapidly changing circumstances, so it's important to create branding that is easy for consumers to remember. It should not be forgotten that other key points are the standardization of products, partnerships, and efficiency of all stages, starting from the input, process, output, and outcome (Heryani et al., 2020).

Optimizing the use of natural resources will be better if skills, knowledge, and creativity accompany it. This will increase the added value than previously. For example, rattan is used as a variety of crafts that have more artistic and high economic value than rattan alone without being processed. Diversity of resources can be used to produce creative industrial products. What is needed from human resources characteristics are creative, capable, or expert. The partnership must be built on the principle of a winwin solution. With good quality human resources, a creative industry will be created to advance this beloved Indonesian nation (Heryani et al., 2020). 
Creative industry development strategies can be carried out through the collaboration of related scholars (such as community leaders, experts in their respective fields, study groups, and researchers), existing business people or entrepreneurs, and the government. This must always be coordinated continuously at all times tirelessly so that the goals of innovation and developing the creative industry are quickly achieved to the maximum. This engagement commitment includes financial and non-financial support. In terms of finance, the financing of development programs for creative industries can be run through government funding, CSR (corporate social responsibility), or through the allocation of research or research funds. Another form is the commitment of educators to teach better every time. Formal and informal meetings face-to-face and online can also be held to provide space for the exchange of information, expertise, skills, knowledge, experience, technology, understanding of the current state of the market, and so on (Heryani et al., 2020).

Standardization of competency for special skills needs to be applied to develop human data resource expertise. Creativity needs to be honed and improved so that the products are more popular among consumers. The best products can compete in the increasingly crowded competitive conditions in the creative industry. The implementation and optimization of technology and information must not be forgotten in the most competitive market conditions (Heryani et al., 2020).

To produce children of the nation with an entrepreneurial spirit, formal education must include entrepreneurship in its curriculum. Support from the community, government agencies, and entrepreneurs who have been in the industry for a long time is needed to create a new generation with a creative entrepreneurial spirit. Maximizing the quality control system, delivering orders on time, controlling the logistics system will make customers feel at home and make repeat purchases (Heryani et al., 2020). For the sake of optimizing the analysis results, it is important to observe the transformation activities and transaction activities. Collaboration with other entrepreneurs is very important to maintain business continuity. Cooperation and continuous improvement are very important for creativity and innovation (Heryani et al., 2020).

\subsection{Value creation by business model theme evolution}

Value creation by business model theme evolution needs critical assessment. Business should be dynamic. The business model theme is related to an evolving industry. Reacting to imitators is essential assessment of product market strategies. Creating new business models means inventing new ways of delivering business to customers. The differences can be activities, transactions, or actors. The efficient business plan is based on low resource usage. The complementarity is business model relies on bundling offerings of good or services. There will be synergies in those bundlings. An example is a travel agency. It offers various transportation, accommodation, insurance, and recommendations. Another business theme alternative is lock-in. This means the more people included in the product, the more adherence will be. An example is Facebook use. The more people usage will increase the more friends and adherence (Climent \& Haftor, 2021).

\subsection{The interaction in business model themes}

The interactions in business model themes are not orthogonal nor exclusive. The interactions have to co-exist with one another with the same business model. The important models are novelty, efficiency, complementarity, and lock-in. The novel business model should be coupled with differentiation and cost leadership to gain firm performance. Customer decision-making is based on knowledge, emotional condition, and social factors. Humans are imaginative creatures. They need innovative changes and improvement for evolution. Therefore, a new business model should be developed based on those factors. Innovation is quickly copied by competitors. A person in business must take creative steps to prevent the stagnant models in the business to obtain the customers' attention (Climent \& Haftor, 2021).

\subsection{The evolution in industry models}

The evolution in industry models is going through interaction with customers, competitors, and regulators. All of them can influence the business model. A business person must create a high-value business for the customers. Innovation and adaptation to the new technologies must be implemented to survive in the global market. The stages of business evolution are birth, growth, maturity, or decline. 
The birth of an industry happens when there are new product or service offerings to the customers. The first steps in business are designing, setting up the delivery, organization, market factors, and values. The greater competition will create various offerings for the customers. Revenues and profits will grow based on the business evolution model and creative ideas. Optimization and productivity are needed to enhance the market values (Climent \& Haftor, 2021).

The consolidation of an industry depends on superior productivity and dominant design. These factors should be patented to prevent the entry of other industries. Innovation of new products is motivated by great rewards. The obstacles in the consolidation of the industry market are the diversity of customers' requirements and the ability for value chain vertical disintegration. Customer preference is associated with their friends' or relatives' preferences (Climent \& Haftor, 2021).

\section{Conclusion}

The paper concludes that strategies to improve the creative economy can be done by increasing the opportunities, challenges, and strengths and minimizing the weakness (SWOT) factors. This can be obtained through SWOT analysis. Increasing the purchases can be implemented by taking the smooth supply chain management and optimizing the e-commerce system. Including entrepreneurship subjects in formal education is essential to increase the entrepreneurship spirit in the young generation.

\section{Limitation and study forward}

The limitation of this article is that a narrative literature review cannot provide comprehensive and detailed data, such as an assessment of the research paper. This paper only cites a small part of the research conducted during the COVID-19 pandemic regarding supply chains and e-commerce. Further studies are suggested to cover strategies for increasing supply chain effectiveness and e-commerce for all types of goods and commodities during the COVID-19 pandemic.

\section{References}

Alexandri, M. B., Zultaqawa, Z., \& Aulia, M. D. (2019). Creative Industries: Strategy and Challenges in the Craft Sub-sector. Review of Integrative Business \& Economics Research, 8(4), 255-263.

Asmah. (2019). Optimalisasi ekonomi kreatif melalui penerapan e-commerce upaya mewujudkan ekonomi kerakyatan pada revolusi industri 4.0. Jurisprudentie, 6(1), 26-39.

Budiono, G. L. (2017). Mapping and selecting company's competitive strategy. European Research Studies Journal, XX(4A), 696-706.

Climent, R. C., \& Haftor, D. M. (2021). Value creation through the evolution of business model themes. Journal of Business Research, 122, 353-361. https://doi.org/10.1016/j.jbusres.2020.09.007

Dewantoro, A. D., \& Saogo, A. (2021). Perumusan Strategi rekomendasi UKM pada masa pandemi Covid-19 (Studi kasus : UD Darmaji ). Performa: Media Ilmiah Teknik Industri, 20(1), 7-13.

Fauziah, \& Vaulina, S. (2020). Kinerja rantai pasok fillet ikan patin beku di desa Koto Mesjid kecamatan XIII Koto Kampar kabupaten Kampar (Suatu kasus pada CV Graha Pratama Fish). Jurnal Agribisnis Indonesia (Journal of Indonesian Agribusiness), 8(2), 115-130.

Flavián, C., Ibáñez-sánchez, S., \& Orús, C. (2019). The impact of virtual , augmented and mixed reality technologies on the customer experience. Journal of Business Research, 100 (October 2018), 547-560. https://doi.org/10.1016/j.jbusres.2018.10.050

Hendarsyah, D. (2019). E-commerce di era industri 4.0 dan society 5.0. IQTISHADUNA: Jurnal Ilmiah Ekonomi Kita, 8(2), 171-184.

Herawaty, T., \& Raharja, S. J. (2018). Creative industry development strategy in Bandung, Indonesia. Review of Integrative Business \& Economics Research, 7(2), 394-403.

Heryani, H., Legowo, A. C., \& Nugroho, I. P. (2020). Strategi pengembangan industri kreatif untuk inovasi. Jurnal Teknologi Industri Pertanian, 30(3), 290-298.

Ibrahim, S., Nurrochmat, D. R., \& Maulana, A. (2019). SMEs development strategy of footwear business. Jurnal Organisasi dan Manajemen, 15(2), 128-140.

https://doi.org/10.33830/jom.v15i2.712.2019

Lestariningsih, E., Maharani, K., \& Lestari, T. K. (2018). Measuring creative economy in Indonesia: 
Issues and challenges in data collection. Asia Pacific Sustainable Development Journal, 25(2), 99-114. https://doi.org/10.18356/16fa938f-en

Rajput, A., Gulzar, S., \& Shafi, K. (2019). Impact of supplier development on supplier performance: Mediating role of trust. Business \& Economic Review, 11(2), 45-66.

Saragih, N. I., Hartati, V., \& Fauzi, M. (2020). Tren , Tantangan , dan perspektif dalam sistem logistik pada masa dan pasca (new normal) pandemik Covid-19 di Indonesia. Jurnal Rekayasa Sistem Industri, 9(2), 77-86. https://doi.org/10.26593/jrsi.v9i2.4009.77-86

Wu, H., \& Han, L. (2021). A novel reasoning model for credit investigation system based on Fuzzy Bayesian Network. Procedia Computer Science, 183, 281-287. https://doi.org/10.1016/j.procs.2021.02.060

Zulkarnain, A., Wahyuningtias, D., \& Putranto, T. S. (2018). Analysis of IFE , EFE and QSPM matrix on business development strategy. IOP Conference Series: Earth and Environmental Science, 126, 1-7. https://doi.org/10.1088/1755-1315/

Zultaqawa, Z., Alexandri, M. B., \& Hardinata, C. (2020). Keunggulan kompetitif pada usaha kecil dan menengah: sebuah studi pemetaan sistematis. AdBispreneur: Jurnal Pemikiran Dan Penelitian Administrasi Bisnis Dan Kewirausahaan, 4(3), 217-228. https://doi.org/10.24198/adbispreneur.v4i3.18646 